\title{
EFFECT OF BIOLOGICAL TREATMENTS OF GREEN CORN STOVER AND STALKS ON DIGESTIBILITY COEFFICIENTS, RUMEN FERMENTATION AND SOME BLOOD PARAMETERS IN SHEEP
}

\author{
Hanan, A.A. Saad ${ }^{1}$; H.M. Gado ${ }^{2}$; T. Draz ${ }^{1}$ and H.M. Metwally ${ }^{2}$ \\ 1- Animal Production Research Institute, Agric. Research Centre, Giza, Egypt \\ 2- Animal Productions Dept., Fac. of Agric., Ain Shams Univ., Cairo, Egypt
}

Keywords: Corn stalks, Corn stover, Silage, Biological Treatment, Cellulose enzymes, ZAD.

\section{ABSTRACT}

This study aimed to investigate the effect of a mixture of (ZAD) and (Lacto bacillus plantarum) on chemical composition of green corn stover and corn stalks and the effect of these treatments in a metabolism trial on digestibility coefficients, rumen fermentation and some blood parameters.

One ton of either green corn stover or corn stalks was chopped into $(2-3 \mathrm{~cm})$ and its mixed with 0.5 cubic metre of water or one cubic metre of water, respectively. They were then mixed with $3 \% \mathrm{w} / \mathrm{w}$ molasses and $1.5 \% \mathrm{w} / \mathrm{w}$ urea and incubated for six weeks. The experiment included six treatments, three of them were on green corn stover and the rest were on corn stalks. The treatments on green corn stover were as follows: (T1) Untreated green corn stover (control). (T2) corn stover + lactobacillus palantarum + ZAD (2litres of $Z A D+1$ liter of lactobacillus palantarum / 1ton). (T3) corn stover + ZAD ( 2 liters of ZAD/ 1 ton). The treatments on corn stalks were as follows: (T4) Untreated corn stalks (control). (T5) corn stalks + lactobacillus palantarum + ZAD (2litres of ZAD +1 liter of lactobacillus palantarum /1ton) (T6) corn stalks + ZAD (2 liters of ZAD/ 1 ton). Eighteen Ossimi male lambs were divided to six group rations for 15 days in metabolism trials. Results indicated that biological treatment on T2 and T3 treatments on green stover and T5 and T6 on dry corn stalks decreased CF and NDF, ADF, ADL contents and increased CP content compared to the control.

Feeding lambs on treated green corn stover or treated dry corn stalks significantly $(\mathrm{P}<0.05)$ improved all of nutrients digestibility compared with those fed on control. The nutritive values as TDN, DCP and $\mathrm{N}$ balance for lambs fed treated green stover or treated dry corn stalks showed significant $(\mathrm{P}<0.05)$ higher than those fed untreated and it had the same trend of nutrient digestibility . Adding lactobacillus palantarum + ZAD improved digestion coefficients of nutrients and TDN values compared with control.

Results of blood parameter indicated that T2 of green corn stover and T5 of corn stalks had a significant $(P<0.05)$ effect on (Tp, Alb, Glb, A/G) compared to the control and T3 of corn stover and T6 of corn stalks. All values of plasma ALT and AST for all treatments were in normal rang where all treatments had no effect on ALT. However, T2 of green corn stover and T5 of corn stalks had a significant $(P<0.05)$ effect on AST compared to the control and T3 of corn stover and T6 of corn stalks. All values of plasma creatinine and urea for biological treatments appeared to significant $(P<0.05)$ higher values. However, these values were in normal range.

Results of rumen parameters indicated that all treatments had no effect on $\mathrm{pH}$ and $\mathrm{NH}_{3}-\mathrm{N}$. On the other hand T2 of green corn stover and T5 of corn stalks significantly $(\mathrm{P}<0.05)$ increased TVF'S. Generally, Adding enzyme with or without lactobacillus to green corn stover or dry corn stalks tended to improved nutrient components, digestibility coefficients, feeding values and nitrogen balance with no adverse effect of animal health .

\section{INTRODUCTION}

In Egypt, there is a limitation in the cultivated area, so there is a wide gap between the available feeds and animals requirements. It was estimated as a shortage of 4.79 million tons of TDN per year 
(El-Ashry, 2007). Thus, there is a serious shortage in animal feeds, causing high negative effects on livestock production.

By-products can play an important role to minimize this gap. The annual agriculture by-products estimated to be around 35 million tons of dry material per year (Ministry of Agriculture and Reclaiming Lands, 2008). The utilization of byproducts can not only be used in favor of solving feed shortage problems but also to prevent environmental pollution. In general there are some factors limiting the utilization of some wastes which have low nitrogen content, high fiber and lignocelluloses content and hence low palatability and digestibility. Some of these wastes are corn stalk and corn stover To maximize the utilization of these wastes as ruminant feeds different treatments as physical, chemical and biological treatments. These treatments can be carried out to destroy the linkages between cellulose, hemicelluloses and lignin (El-Ashry et al 2003 and Galila and Ali, 2005). Incorporating by-products in animal feed in general or after up-grading their nutritive value by mechanical, chemical or biological treatments can also reduce the cost and increase the profit of animal production projects. Biological treatment such as ZAD compound (Gad et al 2005; Gado et al 2006 \& 2007a,b and Ramadan, 2007) can be an approach to convert the low quality agricultural wastes into higher quality feeds for ruminants. Lacto bacillus plantarum treatment can construct a stable and functional lactic acid bacteria community that can be used in the ensilage of the green corn stover and dry corn stalk to improve the taste and flavor. The accumulation of lactic acid amounted to $4.01 \%$ at the end of ensiling ( $\mathbf{L i}$ Qiao Liang Zhang et al 2014).

The objective of the present study was to investigate the impact of biological treatments on chemical composition of green corn stover and dry corn stalks. Moreover, digestibility coefficient, nutritive values, some Rumen Parameter and some blood Parameter were determined.

\section{MATERIALS AND METHODS}

\section{Preparation of corn stover, corn stalks and bio- logical treatment}

\section{Ensiling}

The samples of both green corn stover and corn stalks were chopped into $2-3 \mathrm{~cm}$. One ton of corn stover was mixed with 0.5 cubic metre of wa- ter and one ton of corn stalk was mixed with one cubic metre of water. After that, they were mixed with $3 \% \mathrm{w} / \mathrm{w}$ molasses and $1.5 \% \mathrm{w} / \mathrm{w}$ urea and incubated for six weeks. The experiment included six treatments, three of them were on green corn stover and the rest were on corn stalks. The treatments on green corn stover were as follows: (T1) Untreated green corn stover (control). (T2) Green corn stover + lactobacillus palantarum + ZAD (2litres of ZAD + 1 litre of lactobacillus palantarum/ 1ton). (T3) Green corn stover + ZAD (2 litres of $\mathrm{ZAD} / 1$ ton). The treatments on corn stalks were as follows: (T4) Untreated corn stalks (control). (T5) Corn stalks+ lactobacillus palantarum + ZAD (2litres of ZAD + 1 litre of lactobacillus palantarum/ 1ton) and (T6) Corn stalks + ZAD (2 litres of ZAD/ 1 ton)

\section{Metabolism trial}

Eighteen Ossimi male lambs were divided into six groups ( 3 animals in each) and allowed to receive six experimental rations for 15 days. All animals fed concentrate feed mixture with rate of $1 \%$ of LBW. Animals were dwelled in metabolic cages for seven days as a preliminary period. Feces and urine were collected during the next seven days. Samples represented tenth of the voided feces and excreted urine were taken daily just after collection. Urine samples were stored in tight bottles containing sulfuric acid (1:1) and refrigerated at $4{ }^{\circ} \mathrm{C}$ for nitrogen determination. Fecal samples were weighted and dried at $60^{\circ} \mathrm{C} / 12 \mathrm{hrs}$. in a hot oven. Dried samples of feces and feeds were ground to pass through 1-mm sieve, and were stored in emeried bottles for chemical analysis. Meanwhile, digestion coefficient and nutritive value of the experimental rations were calculated.

\section{Sampling of rumen liquor}

Rumen contents were sampled by a stomach tube from all animals of each group at the final day of the metabolism trial. The samples were taken before the morning feeding ( 0 time) and at 3 and 6 hours after feeding. The rumen samples were filtered through four layers of cheese-cloth and used quickly as possible for the measurement of $\mathrm{pH}$. Strain rumen liquor was stored in glass bottles $(45$ $\mathrm{ml}$ ) with few drops of toluene and paraffin oil just to cover the surface and stored at a deep freezer $\left(-18^{\circ} \mathrm{C}\right)$ till analysis for ammonia nitrogen $\left(\mathrm{NH}_{3}-\mathrm{N}\right)$ and total volatile fatty acids (TVFA'S ). 


\section{Sampling of blood}

Blood samples were collected at the final day of collecting period from all animals of each group. A sample of $10 \mathrm{ml}$ of blood per animal was collected from the jugular vein through heparin tubes after morning feeding. Then, it was centrifuged for 20 min., while the plasma samples were directly collected into clean dried tube and stored at a deep freezer $\left(-18^{\circ} \mathrm{C}\right)$ till analysis for chemical analysis.

\section{Chemical analysis}

The proximate analysis of feeds, feces and urine were carried out according to the conventional method of A.O.A.C. (2005). Cell wall constituents were determined according to Goering and Van Soest (1970) and van Soest et al (1991)

\section{Rumen liquor analysis}

\subsection{Rumen $\mathrm{pH}$ value}

Rumen $\mathrm{pH}$ was determined (before rumen liquor storage) by using a hand- held $\mathrm{pH}$ electrode (model M90, corning, NY).

\subsection{Ammonia nitrogen $\left(\mathrm{NH}_{3}-\mathrm{N}\right)$}

Ammonia- $\mathrm{N}$ were determined by the modified semi-micro kjeldahl digestion method according to A.O.A.C. (2005).

\subsection{Total volatile fatty acids (TVFA's )}

Rumen total volatile fatty acids (TVFA 's) were determined by steam distillation as described by Warner (1964)

\section{Blood plasma analysis}

The blood plasma parameters were determined by using commercial kits as follows:

\subsection{Total protein}

Plasma Total protein was measured calorimetrically according to the method of Cannon et al (1974).

\subsection{Albumin}

Plasma albumin was determined calorimetrically according to the method of Dumas and Biggs (1972).

\subsection{Globulin}

Plasma globulin was calculated by subtracting the value of albumin from the corresponding value of total protein for each sample.

\subsection{Albumin: Globulin ratio (A/G ratio)}

The $A / G$ ratio was calculated by dividing each albumin value by its corresponding globulin value.

\subsection{Transaminases}

Plasma aspartate aminotransferase (AST) and alanine aminotransferase (ALT) were determined calorimetrically according to method of Reitman and Frankel (1957)

\subsection{Urea}

Plasma urea was determined calorimetrically according to method of Henry et al.(1974).

\subsection{Creatinine}

Plasma Creatinine was determined calorimetrically according to the method of Spierto et al.(1979).

\section{Statistical analysis}

Data were statistically analyzed using general liner of SAS (2001). Significant differences between means were tested by multiple rang test (Duncan ,1955). The model was as follows:

$$
\mathbf{Y i j}=\boldsymbol{\mu}+\mathrm{Ti}+\boldsymbol{\alpha i j} \ldots \ldots \ldots \ldots \ldots \text { where . }
$$

Yij $=$ the observation of the model.

$\mu=$ general mean common element to all observation

$\mathrm{Ti}=$ effect of the treatment $(\mathrm{i}=1 \ldots .6)$

aij $=$ the experimental error

\section{RESULTS AND DISCUSSION}

The chemical composition of DM and its component and CF fractions for green corn stover are shown in Table (1). Both green corn stover treatments (T2 and T3) contained higher DM (91.90 and 91.70 respectively vs. $85.88 \%$ for $\mathrm{T} 1)$; CP (19.04 and 18.65 vs.8.16\%); Ash (7.72 and 7.63 vs.5.24\%); NFE (42.44 and 41.66 vs. $41.26 \%$ ). 
Table 1. Effect of biological treatments on chemical composition of green corn stover (on DM basis)

\begin{tabular}{|c|c|c|c|c|c|c|c|c|c|c|}
\hline Item & DM & OM & CP & EE & CF & NFE & ASH & NDF & ADF & ADL \\
\hline T1 & $85.88^{\mathrm{b}}$ & $94.76^{\mathrm{a}}$ & $8.16^{\mathrm{b}}$ & 4.66 & $40.68^{\mathrm{b}}$ & $41.26^{\mathrm{b}}$ & $5.24^{\mathrm{b}}$ & $89.50^{\mathrm{a}}$ & $60.00^{\mathrm{a}}$ & $20.00^{\mathrm{a}}$ \\
T2 & $91.90^{\mathrm{a}}$ & $92.28^{\mathrm{b}}$ & $19.04^{\mathrm{a}}$ & 4.79 & $26.01^{\mathrm{a}}$ & $42.44^{\mathrm{a}}$ & $7.72^{\mathrm{a}}$ & $65.80^{\mathrm{b}}$ & $39.50^{\mathrm{c}}$ & $15.00^{\mathrm{b}}$ \\
T3 & $91.70^{\mathrm{a}}$ & $92.37^{\mathrm{b}}$ & $18.65^{\mathrm{a}}$ & 4.91 & $27.15^{\mathrm{a}}$ & $41.66^{\mathrm{a}}$ & $7.63^{\mathrm{a}}$ & $67.10^{\mathrm{b}}$ & $40.30^{\mathrm{b}}$ & $15.00^{\mathrm{b}}$ \\
SE & \pm 0.17 & \pm 0.20 & \pm 0.05 & \pm 0.10 & \pm 0.20 & \pm 0.32 & \pm 0.11 & \pm 0.27 & \pm 0.26 & \pm .022 \\
\hline
\end{tabular}

$a$ and $b$ : Means with different superscripts in the same column are significant $(P<0.05)$

Where: (T1) Untreated green corn stover (control).

(T2) Green corn stover + lactobacillus palantarum + ZAD of lactobacillus

(T3) Green corn stover + ZAD

While control group (T1) recorded the highest OM (94.76 vs. $92.28 \%$ for T2 and 92.37 for T3); CF (40.68 vs.26.01 and $27.15 \%)$; NDF (89.5vs. 65.8 and $67.1 \%)$; ADF (60.00 vs. 39.50 and $40.30 \%)$; ADL (20.00vs.15.00 and15.00\%). These results were in agreement with the findings of Yang et al (2010). The reduction in CF and fiber fractions contents of T2 and T3 may be due to the influence of cellulase enzymes secreted by bacteria that break down the linkage between structure carbohydrate and lignin (Fazaeli et al 2004) while, the bacteria treatment increased $\mathrm{CP}$ and ash contents of treated. The increase in CP content of treated groups (T2 and T3) may be due to the relatively high protein content in urea and growth of bacteria (Mariel et al 2011) while, the increase in ash content may reflect the decrease in OM content (Yang et al 2010).

Data presented in Table (2) showed the chemical composition of corn stalks alone or with additives. T5and T6 had significantly $(\mathrm{P}<0.05)$ higher of DM, being (89.30and $89.10 \%)$ respectively and the T4 had $(85.50 \%)$. T4 recorded higher significant of OM $(97.78 \%)$, versus (89.03 and $85.40 \%)$ for T4 and T6, respectively.T5 and T6 had higher significant of $\mathrm{CP}$, being 18.03 and $16.84 \%$, respectively than those of T4 (3.47\%). The same trend was observed with EE percentage, which T5 and T6 recorded 6.83 and $6.07 \%$, respectively, while T4 recorded $4.68 \%$. The opposite trend was observed with CF. T4 showed the highest CF (54.39\%) compared to T5and T6 (27.99 and $31.43 \%$ respectively). With respect to NFE percentage, it could be noticed that the NFE \% showed higher values with $\mathrm{T} 5(36.18 \%)$ and lower values recorded with T6 $(31.06 \%)$, while T4 recorded $35.24 \%$. Data revealed that the $C F$ fractionations as NDF, ADF and ADL showed significantly higher percentage with T4 than those of T5 and T6, as shown in (Table 2).

Data presented in Table (3) showed significantly $(P<0.05)$ higher digestibility coefficient for $D M$, $\mathrm{OM}, \mathrm{CP}, \mathrm{CF}$ and NFE with T2 and T3 than those found with $\mathrm{T} 1$. However, EE digestibility coefficient showed significant $(P<0.05)$ increase with $T 2$ and not significant with T3 compared with those of T1.

Increasing of all nutrient digestibility with T2 and T3 might be attributed to supplemented green corn stover with either lactobacillus and ZAD or ZAD only in T2 and T3, respectively. The nutritive values expressed as TDN and DCP showed the same previous trend, recording 69.10 and $16.91 \%$ for T2 versus 65.30 and $15.70 \%$ for T3.

Table 2. Effect of biological treatments on chemical composition of corn stalks (on DM basis)

\begin{tabular}{|c|c|c|c|c|c|c|c|c|c|c|}
\hline Item & DM & OM & CP & EE & CF & NFE & ASH & NDF & ADF & ADL \\
\hline T4 & $85.50^{\mathrm{b}}$ & $97.78^{\mathrm{a}}$ & $3.47^{\mathrm{c}}$ & $4.68^{\mathrm{b}}$ & $54.39^{\mathrm{a}}$ & $35.24^{\mathrm{a}}$ & $2.22^{\mathrm{b}}$ & $85.10^{\mathrm{a}}$ & $57.30^{\mathrm{a}}$ & $23.00^{\mathrm{a}}$ \\
T5 & $89.30^{\mathrm{a}}$ & $89.03^{\mathrm{b}}$ & $18.03^{\mathrm{a}}$ & $6.83^{\mathrm{a}}$ & $27.99^{\mathrm{c}}$ & $36.18^{\mathrm{b}}$ & $10.97^{\mathrm{a}}$ & $72.30^{\mathrm{a}}$ & $50.10^{\mathrm{b}}$ & $15.00^{\mathrm{c}}$ \\
T6 & $89.10^{\mathrm{a}}$ & $85.40^{\mathrm{c}}$ & $16.84^{\mathrm{b}}$ & $6.07^{\mathrm{a}}$ & $31.43^{\mathrm{b}}$ & $31.06^{\mathrm{b}}$ & $14.60^{\mathrm{a}}$ & $77.00^{\mathrm{c}}$ & $43.30^{\mathrm{c}}$ & $19.00^{\mathrm{b}}$ \\
SE & \pm 0.48 & \pm 0.50 & \pm 0.08 & \pm 0.08 & \pm 0.34 & \pm 0.67 & \pm 0.07 & \pm 0.33 & \pm 0.24 & \pm 0.2 \\
\hline
\end{tabular}

a, b and C: Means with different superscripts in the same column are significant $(\mathrm{P}<0.05)$

Where: (T4) Untreated dry corn stalks (control).

(T5) dry corn stalks + lactobacillus palantarum + ZAD of lactobacillus

(T6) dry corn stalks+ ZAD 
Table 3. Effect of treatments on apparent nutrient digestibility and nutritive values of green corn stover rations (\%)

\begin{tabular}{|c|c|c|c|c|c|c|c|c|c|}
\hline Item & DM & OM & CP & EE & CF & NFE & TDN & DCP & NB \\
\hline T1 & $73.10^{\mathrm{b}}$ & $74.10^{\mathrm{b}}$ & $67.60^{\mathrm{b}}$ & $86.50^{\mathrm{b}}$ & $81.60^{\mathrm{b}}$ & $68.00^{\mathrm{b}}$ & $59.60^{\mathrm{b}}$ & $5.52^{\mathrm{c}}$ & $+4.70^{\mathrm{c}}$ \\
T2 & $88.60^{\mathrm{a}}$ & $87.50^{\mathrm{a}}$ & $88.80^{\mathrm{a}}$ & $94.10^{\mathrm{a}}$ & $88.30^{\mathrm{a}}$ & $85.70^{\mathrm{a}}$ & $69.10^{\mathrm{a}}$ & $16.91^{\mathrm{a}}$ & $+9.30^{\mathrm{b}}$ \\
T3 & $82.40^{\mathrm{a}}$ & $84.00^{\mathrm{a}}$ & $84.20^{\mathrm{a}}$ & $89.90^{\mathrm{b}}$ & $89.90^{\mathrm{a}}$ & $77.10^{\mathrm{a}}$ & $65.30^{\mathrm{a}}$ & $15.70^{\mathrm{b}}$ & $+11.00^{\mathrm{a}}$ \\
\hline SE & \pm 1.9 & \pm 2.0 & \pm 3.0 & \pm 1.7 & \pm 1.4 & \pm 2.7 & \pm 1.6 & \pm .39 & \pm 0.32 \\
\hline
\end{tabular}

a, b and C: Means with different superscripts in the same column are significant $(\mathrm{P}<0.05)$

Where:

(T1) Untreated green corn stover (control).

(T2) Green corn stover + lactobacillus palantarum + ZAD of lactobacillus

(T3) Green corn stover + ZAD

Increasing in nutritive values for supplemented green corn stover (T2 and T3) might be due to higher digestibility coefficients of all nutrients than those of control (T1). In this respect, NB with T2 and $\mathrm{T} 3$ tended to significantly $(\mathrm{P}<0.05)$ positive, being +9.30 and +11.00 , respectively.

Data presented in Table (4) showed significantly $(P<0.05)$ higher digestibility coefficient for $D M$, $\mathrm{OM}, \mathrm{CP}$ and NFE with T5 and T6 than those found with $\mathrm{T} 4$, while increasing in digestibility coefficients of CF were not significant. However, EE digestibility coefficient showed significant $(\mathrm{P}<0.05)$ increase with $\mathrm{T} 5$ and not significant with $\mathrm{T} 6$ compared to those of T4. Salem et al $(2007 \mathbf{a}, \mathbf{b})$ found that addition of ZADO compound improved $(\mathrm{P}<0.05)$ all nutrients digestibility. Sutton et al (2003) and Pinos-Rodriguez et al (2007) found that there were insignificant differences between enzymes and control treatments in digestibility for most nutrients. Gad et al (2005); Gado et al (2007a) and Ramadan (2007) found that ZAD compound increased significantly $(\mathrm{P}<0.05)$ all nutrient digestibility com pared with control. Also, Beauchemin et al (1999) and Bowman et al (2002) found that enzyme supplementation increased $(\mathrm{P}<0.06)$ digestibility of $\mathrm{OM}$ and fiber of barley compared with the control diet.
Moreover, Yang et al (2002) found that digestibilities of DM, OM, and CF were increased $(P<0.05)$ owing to enzyme supplementation. Titi \& Tabbaa (2004) and Abdel-Gawad et al (2007) found that fibrolytic enzyme contained cellulase increased $(\mathrm{P}<0.05) \mathrm{DM}, \mathrm{OM}, \mathrm{CF}, \mathrm{NDF}$ and ADF digestibilities compared with control. Moreover, Gado et al (2007b) found that biological treatments by cellulase; rumen liquor and Cellumonas cellulasea for bagasse had significantly positive effect on DM, $\mathrm{CP}$ digestibility. However, cellulase enzyme increased $(P<0.05)$ the percent of DM digestibility coefficient when compared with other treatments. Crude fiber digestibility of treated bagasse with rumen liquor was the highest, while Cellumonas cellulasea was the lowest. In general, enzyme treatment positively affected digestibility of $\mathrm{OM}$, EE, NFE.

Increasing of all nutrient digestibility withT5 and T6 might be attributed to supplemented corn stalk with either lactobacillus and ZAD or ZAD only in T5 and $T 6$, respectively. The nutritive values expressed as TDN and DCP showed the same previous trend, recording 69.20 and $15.70 \%$ for T5 versus 65.40 and $13.40 \%$ for T6. .

Table 4. Effect of treatments on apparent nutrient digestibility and nutritive values of dry corn stalks rations (\%)

\begin{tabular}{|c|c|c|c|c|c|c|c|c|c|}
\hline Item & DM & OM & CP & EE & CF & NFE & TDN & DCP & NB \\
\hline T4 & $73.10^{\mathrm{b}}$ & $73.20^{\mathrm{b}}$ & $42.50^{\mathrm{b}}$ & $77.50^{\mathrm{b}}$ & $85.90^{\mathrm{a}}$ & $59.20^{\mathrm{b}}$ & $54.90^{\mathrm{b}}$ & $1.47^{\mathrm{C}}$ & $+4.90^{\mathrm{C}}$ \\
T5 & $86.10^{\mathrm{a}}$ & $87.60^{\mathrm{a}}$ & $87.10^{\mathrm{a}}$ & $94.30^{\mathrm{a}}$ & $89.30^{\mathrm{a}}$ & $85.20^{\mathrm{a}}$ & $69.20^{\mathrm{a}}$ & $15.70^{\mathrm{a}}$ & $+9.60^{\mathrm{b}}$ \\
T6 & $82.40^{\mathrm{a}}$ & $83.50^{\mathrm{a}}$ & $79.60^{\mathrm{a}}$ & $79.80^{\mathrm{b}}$ & $87.10^{\mathrm{a}}$ & $83.90^{\mathrm{a}}$ & $65.40^{\mathrm{a}}$ & $13.40^{\mathrm{b}}$ & $+11.00^{\mathrm{a}}$ \\
SE & \pm 1.7 & \pm 1.8 & \pm 2.3 & \pm 3 & \pm 1.49 & \pm 1.9 & \pm 1.45 & \pm 0.32 & \pm 0.11 \\
\hline
\end{tabular}

a, b and $\mathrm{C}$ : Means with different superscripts in the same column are significant $(\mathrm{P}<0.05)$

Where: (T4) Untreated dry corn stalks (control).

(T5) dry corn stalks + lactobacillus palantarum + ZAD of lactobacillus

(T6) dry corn stalks+ ZAD 
Increasing in nutritive values for supplemented corn stalks (T5 and T6) might be due to higher digestibility coefficients of all nutrients than those of control (T4). In this respect, NB with T5 and T6 tended to be significantly $(P<0.05)$ positive, being +9.60 and +11.0 , respectively. These increases in TDN and DCP values may be due to the higher apparent nutrient digestibilities coefficients. These results were in good agreement with the findings of Abdel-Gawad et al (2007) who reported higher values of TDN and DCP for xylanase and cellulase treated corn stalks and wheat straw compared with control. Ramadan (2007) found that biological treatments by ZAD compound increased the nutritive value as TDN and DCP of wheat straw and bean straw compared with control. Salem et al $(2007 a, b)$ indicated that the nutritive value improved by adding ZADO in ruminant rations.

The results indicate in general that biological treatments improved TDN and DCP of green corn stover and dry corn stalks compared with untreated green corn stover and corn stalks.

Effect of treatments of green corn stover and dry corn stalks on some rumen liquor parameters.

Rumen $\mathrm{pH}$ values showed no significant differences in all treatments as shown in Table (5). The differences in green corn stover with respect to TVF's were significant $(p<0.05)$, recording the highest concentration with T2 $(12.20 \mathrm{mg} / \mathrm{dl})$ followed by T3 $(11.20 \mathrm{mg} / \mathrm{dl})$ and the lowest concentration recorded with $\mathrm{T} 1(10.50 \mathrm{mg} / \mathrm{dl})$. Mean values of ruminal ammonia $-\mathrm{N}$ showed the same trend of TVF's with no significant difference, as shown in Table (5).

Table 5. Some rumen parameters of lambs fed different green corn stover treatments

\begin{tabular}{|c|c|c|c|}
\hline Item & $\mathbf{p H}$ & $\begin{array}{c}\text { TVFA } \\
\text { [mg/dl(100ml] }\end{array}$ & $\begin{array}{c}\text { NH3- } \\
\mathbf{N}[\mathbf{m g} / \mathbf{d l} \\
(\mathbf{1 0 0 m I})\end{array}$ \\
\hline T1 & 6.40 & $10.50^{\mathrm{c}}$ & 11.40 \\
T2 & 6.60 & $12.20^{\mathrm{a}}$ & 12.60 \\
T3 & 6.60 & $11.20^{\mathrm{b}}$ & 11.90 \\
\hline SE & \pm 0.02 & \pm 0.15 & \pm 0.61 \\
\hline
\end{tabular}

$a, b$ and $C$ : Means with different superscripts in the same column are significant $(P<0.05)$

Where:

(T1) Untreated green corn stover (control).

(T2) Green corn stover + lactobacillus palantarum + ZAD of lactobacillus

(T3) Green corn stover + ZAD
With respect to corn stalk treatment, it could be noticed that the ruminal $\mathrm{pH}$ values as shown in Table (6). Recorded 6.5, 6.6 and 6.6 with T4, T5 and $\mathrm{T} 6$ respectively, showing no significant differences as shown in table 6. Beauchemin et al (1999), Yang et al (1999), Bowman et al (2002), Sutton et al (2003) and Pinos-Rodriguez et al (2007) reported that ruminal $\mathrm{pH}$ was not affected by enzymes treatments. Also, Gado et al (2007b) noticed that biological treatments (cellulase; rumen liquor and cellumonas cellulasea) had no effect on rumen liquor $\mathrm{pH}$ values. Abdel-Gawad et al (2007) found that fibrolytic enzymes composed of $x y$ lanase and cellulase had no significant effect $(\mathrm{P}<0.05)$ on rumen liquor $\mathrm{pH}$ values. The differences in dry corn stalks with respect to TVF'S were significant $(P<0.05)$, recording the highest concentration with T5 $(11.70 \mathrm{mg} / \mathrm{dl})$ followed by T6 (10.80 $\mathrm{mg} / \mathrm{dl}$ ) and the lowest concentration recorded with $\mathrm{T} 4(10.10 \mathrm{mg} / \mathrm{dl})$. These results were in agreement with the findings of Abdel-Gawad et al (2007) who found that TVFA's concentration of rumen liquor showed significant $(\mathrm{P}<0.05)$ increase with lambs fed xylanase and cellulase treated corn stalks and wheat straw compared with those of control.

Mean values of ruminal ammonia $-\mathrm{N}$ showed the same trend of TVF'S with no significant difference, as shown in Table (6). These results are in good agreement with the findings of Kholif (2006) who noticed that ruminal ammonia nitrogen increased $(P<0.05)$ with fibrolytic enzyme treatment compared with control.

Table 6. Some rumen parameters of lambs fed different dry corn stalks treatments

\begin{tabular}{|c|c|c|c|}
\hline Item & pH & $\begin{array}{c}\text { TVFA(mg/ } \\
\text { dl(100ml) }\end{array}$ & $\begin{array}{c}\text { NH3- } \\
\mathbf{N}(\mathbf{m g} / \mathbf{d l}(\mathbf{1 0 0} \mathbf{m l})\end{array}$ \\
\hline T4 & 6.50 & $10.10^{\mathrm{c}}$ & 11.40 \\
T5 & 6.60 & $11.70^{\mathrm{a}}$ & 12.60 \\
T6 & 6.60 & $10.80^{\mathrm{b}}$ & 11.70 \\
\hline SE & \pm 0.25 & \pm 0.18 & \pm 0.53 \\
\hline
\end{tabular}

$a, b$ and $C$ : Means with different superscripts in the same column are significant $(P<0.05)$

Where:

(T4) Untreated dry corn stalks (control).

(T5) dry corn stalks + lactobacillus palantarum + ZAD of lactobacillus

(T6) dry corn stalks+ ZAD 


\section{Effect of treatments of green corn stover on some blood plasma parameters.}

Effect of treatments on the overall means of Plasma total protein (TP) were significant $(\mathrm{P}<0.05)$. T2 recorded the highest concentration (7.70) compared to $\mathrm{T} 3$ and $\mathrm{T} 1(7.3$ and $7.3 \mathrm{~g} / 100 \mathrm{ml}$ respectively). The values of plasma total protein were within the normal range.

The overall means of plasma albumin (ALB) were $4.10,4.90$ and 4.50 for T1, T2 and T3 respectively. Significant differences $(P<0.05)$ were detected among all groups showing the highest concentration of albumin with T2. The present values of plasma albumin were within the normal range

The overall means of plasma globulin (GLP) were $3.70,2.80$ and $2.40 \mathrm{~g} / 100 \mathrm{ml}$ ) for T2, T3and $\mathrm{T} 1$ respectively. There was a significant difference $(P<0.05)$ among all groups showing the highest values obtained with T2. The present values of plasma globulin were within the normal range.

The overall means of plasma ( $A / G$ ratio) were 2.1, 2.1 and 1.6 for T1, T2 and T3, respectively. It was significantly higher with $\mathrm{T} 1$ and $\mathrm{T} 2$ compared to T3.

There were no significant differences in ALT among different treatments, recording 18.30, 18.80 and $17.00 \mathrm{gm} / 100 \mathrm{ml}$ for T1, T2 and T3, respectively. The present values of plasma (ALT) were within the normal range.

On the other hand, plasma (AST) were 69.00, 65.90 and $62.00 \mathrm{gm} / 100 \mathrm{ml}$ for T2,T3 and T1 respectively, showing significant $(\mathrm{P}<0.05)$ differences among treatments.

The overall means of plasma Creatinine recorded $1.00,1.40$ and $1.30 \mathrm{mg} / \mathrm{dl}$ for T1, T2 and T3, respectively. T2 and T3 recorded the highest $(p<0.05)$ values compared with $T 1$. The present values of plasma Creatinine were within the normal range.

The overall means of plasma urea showed the same previous trend of creatinine recording 36.30, 41.20 and $41.50 \mathrm{mg} / \mathrm{dl}$ for T1, T2 and T3, respectively. The T2 and T3 recorded the highest $(\mathrm{P}<0.05)$ value compared to $\mathrm{T} 1$. The present values of plasma urea were within the normal range.

\section{Effect of treatments of dry corn stalks on some plasma parameters.}

The overall means of Plasma total protein showed significant $(P<0.05)$ differences among group. T5 recorded the highest concentration (8.20 $\mathrm{gm} / 100 \mathrm{ml}$ ) compared with T6 and T4 (6.10 and
$5.70 \mathrm{gm} / 100 \mathrm{ml}$, respectively). The values of plasma total protein were within the normal range. Gad et al (2005) and Ramadan (2007) found that serum total protein was increased with ZAD compound compared with untreated group.

The overall means of plasma albumin were 4.90, 4.50 and $4.30 \mathrm{~g} / 100 \mathrm{ml}$ for T5, T6 and T4, respectively. A significant difference $(p<0.05)$ was detected among all treatments. The present values of plasma albumin were within the normal range. Ramadan (2007) found that serum albumin increased with ZAD treated wheat straw compared with control.

The overall means of plasma globulin showed the same trend of albumin, being 1.20, 3.30 and $1.80 \mathrm{~g} / \mathrm{ml}$ for T4, T5 and T6, respectively. The present values of plasma globulin were within the normal range.

The overall means of plasma ( $A / G$ ratio) cleared significant $(P<0.05)$ differences among treatments. The values were affected by albumin and globulin values, indicating highest ratio with T4.

The overall means of plasma $(A L T)$ were 19.30, 19.50 and 20.00 unite/ml for T3, T2 and T1, respectively. There is no significant differences among treatment groups. The present values of plasma (ALT) were within the normal range.

The overall means of plasma (AST) were $66.00,68.00$ and 69.00 unite/ml for T5,T6 and T4 respectively, showing significant $(p<0.05)$ differences among the treatment. However, the present values of plasma (AST) were within the normal range. The present values of AST and ALT were within the normal values and indicated normal activity of the animal hepatic tissues. Consequently, different biological treatments applied in the present investigation could be used without any adverse effect on the liver functions.

The overall means of plasma Creatinine recorded 1.00, 1.50 and $1.00 \mathrm{mg} / \mathrm{dl}$ for T4, T5 and T6, respectively. T5 recorded the highest $(P<0.05)$ values compared with $\mathrm{T} 4$ and $\mathrm{T} 6$. the present values of plasma Creatinine were within the normal range.

The overall means of plasma urea showed the same trend of creatinine, being 23.50, 28.30, and $25.80 \mathrm{mg} / \mathrm{dl}$ for T4,T5 and T6, respectively. T5 recorded the highest $(\mathrm{P}<0.05)$ value compared to both T4 and T6. The present values of plasma urea were within the normal range. Gad et al (2005) found that plasma urea concentration increased in ZAD treated groups compared with untreated. 
The present values of creatinine and urea are within the normal values and indicated normal activity of the animal kideny tissues. Consequently, different biological treatments applied in the present investigation could be used without any adverse effect on the kidney functions.

Generally, it could be noticed that, biological treatments for green corn stover or corn stalks tended to improve digestibility coefficients and nutritive values. Moreover, some rumen and blood parameters had not been affected by these treatments and these biological treatments could be applied without any adverse effect on animal health.

\section{REFERENCES}

Abdel-Gawad, T.M., Sawsan M. Gad, Eman H. El-Sabaawy, H.M. Ali and Bedawy, T.M. 2007. In vitro and in vivo digestability of some low quality roughage supplemented with fibrolytic enzyme for sheep. Egyptian J. Nutrition and Feeds, 10 (2) (Special Issue), 663-677.

A.O.A.C. 2005. Official Methods of Analysis of AOAC International. $18^{\text {th }}$ Ed. Published by AOAC International Gaithersburg, Maryland, USA.

Beauchemin, K.A., Yang, W.Z. and Rode, L.M. 1999. Effects of grain source and enzyme additive on site and extent of nutrient digestion in dairy cows. J. Dairy Sci., 82, 378-390.

Bowman, G.R., Beauchemin, K.A. and Shelford, J.A. 2002. The proportion of the diet to which fibrolytic enzymes are added affects nutrient digestion by lactating dairy cows. J. Dairy Sci., 85, 3420-3429.

Cannon, D.C., Olitzky, I. and Inkpen, J.A. 1974. Proteins, in Clinical Chemistry Principles and Techniques, $2^{\text {nd }}$ Ed., Henry, R.J, Cannon, D.C. and Winkelman, J.W. (eds), Harper \& Row, Publishers, Hagerstown, MD, pp. 411421.

Dumas, B.T. and Biggs, H.G. 1972. Standards Methods of Clinical Chemistry Vol. 7, Academic press, New York, USA, 175 p.

Duncan, D.B. 1955. Multiple range and multiple $F$ test. Biometric, 11, 1-42.

El-Ashry, M.A., El-Sayed, H.M., Fadel, M., Alamy H.M.H.A. and Kholif, S.M. 2003. Effect of biological treatments on chemical composition, invitro and in-vivo nutrients digestibility of poor quality roughages. Egypt. J. Nutr. and Feeds, 6, 1110.
El-Ashry, M.A. 2007. Animal recourses in the frame of the Egyptian agriculture development. Horizons of animals resource development ruminants. Ministry of agriculture. Agricultural Research Center, Giza, Egypt. (In Arabic). pp. 37-42.

Fazaeli, H., Mahmodzadeh, H., Azizi, A., Jelan Z.A., Liang, J.B., Rouzbehan, Y. and Osman, A. 2004. Nutritive value of wheat straw treated with bacteria. Asian Aus. J. Anim. Sci., 17, 1681-1690.

Gad, A.M., Gado, H. and Metwally, H.M. 2005. Effect of ZAD as a biological additive on the performance of small ruminantes fed rations based on agriculture by-products. Res. Bult., Ain Shams Univ., Cairo, Egypt. pp. 35-37.

Gado, H., Sohair, A. Nasr, Bahira K. Mohamed and Mahrous, A.A. 2006. Effect of biological treatments on the nutritive value of rice straw. Egyptian J. Nutrition and Feeds, 9(2), 207219.

Gado, H.M., Ramadan, F., Mourad, M. and Matter, B.B. 2007a. Effect of biological treatments of some agriculture by-products on ration digestibility and lamb performance. Egyptian J. Nutrition and Feeds, 10(2), Special Issue, 509-516

Gado; H.M., Metwally H.M., EL-Basiony, A.Z.; Soliman, H.S. and Etab R.I. Abd El-Galil 2007b. Effect of biological treatments on sugarcane bagasse digestibility and performance of baldi goats. Egyptian J. Nutrition and Feeds, 10(2) Special Issue, 535-551.

Galila, A.M. and Ali A.M. 2005. Improving efficiency of fungal treatment of banana wastes used as animal feed. J. Biol. Pharm. Sci., 3, 62-71.

Goering, H.K. and Van Soest, P.J. 1970. Forage fiber analysis. Agriculture Handbook No.379, ARS, USDA, Washington, DC., USA.

Henary, R.J. 1974. Clinical Chemistry, Principles and Techniques, $2^{\text {nd }}$ Ed., Harper and row, p 525.

Kholif, S.M. 2006. Effect of improving the nutritional value poor quality roughages on the yield and composition of goat's milk. Egyptian J. Dairy Sci., 34, 197-205.

Li, Qiao Liang, Zhang, Jian Guo, Wei, Zhao Jun 2014. Isolation and characterization of lactic acid bacteria used for ensiling bamboo-shoot shell. British Biotechnology J., 4(4), 511-519.

Mariel, M., Ortegab, I., Ramírezb, M., Baezaa, J. and Freer, J. 2011. Structural change in wood by brown rot fungi and effect on enzymatic hy- 
drolysis. Enzyme and Microbial Technology, 49, 472- 485.

Ministry of Agriculture and Reclaiming lands. 2008. Agricultural Economic, Bull. Central Dept. of Agric., Economics, Cairo, Egypt.

Pinos-Rodriguez, J.M., Moreno, R., Gonzalez, S.S., Robinson, P.H., Mendoza, G. and Alvarez, G., 2007. Effects of exogenous fibrolytic enzymes on ruminal fermentation and digestibility of total mixed rations fed to lambs. Anim. Feed Sci. Technol.,

Ramadan, F. 2007. Biological Treatment of Agric. by Products and their Effect on Lambs Performance. M.Sc. Thesis, Anim. Prod. Dept., Fac. of Agric., Ain Shams. Univ, Cairo, Egypt. pp. 60-63.

Reitman S. and Frankel, S. 1957. A colorimetric method for the determination of serum glutamic oxalacetic and glutamic pyruvic transaminases. Am. J. Clin. Pathol., 28(1), 56-63.

Salem, A.Z.M., Hassan, A.A., Kalil, M.S., Yacout M.H. and Gado H. 2007a. Feed intake, digestibility coefficients, nitrogen utilization and loss of secondary compounds in whole gastrointestinal tract in sheep fed Atriplex halimus foliages in presence of ZADO as direct fed microbials. The $12^{\text {th }}$ Seminar of the FAO-CIHEAM SubNetwork on Sheep and Goat Nutrition, Nutritional and Foraging Ecology of Sheep and Goats Thessaloniki, Greece.

Salem, A.Z.M., El-Adawy, M., Gado, H. and Khalil, M. 2007b. Feed intake, nutrient digestibility and animal growth performance in sheep and goats fed wheat straw ad lib. in presence of ZADO as direct feed of anaerobic enzymes and bacteria. The $12^{\text {th }}$ Seminar of the $\mathrm{FAO}-\mathrm{Cl}$ HEAM Sub-Network on Sheep and Goat Nutrition: Nutritional and foraging ecology of sheep and goats Thessaloniki, Greece.
SAS, 2001. Statistical Analysis System. SAS User's Guide Statistics. SAS Institute Inc. Editors, Cary, NC.

Spierto, F.W., McNeil, M.L. and Burtis, C.A. 1979. The effect of temperature and wavelength on the measurement of creatinine with the jaffe procedure. Clin. Biochem., 12, 18-21.

Sutton, J. D., Phipps, R.H., Beever D.E., Humphries, D.J., Hartnell, G.F., Vicini, J. L. and Hard, D.L. 2003. Effect of Method of Application of a Fibrolytic Enzyme Product on Digestive Processes and Milk Production in Holstein Friesian Cows. J. Dairy Sci., 86. 546-556.

Titi, H.H. and Tabbaa M.J. 2004. Efficacy of exogenous cellulase on digestibility in lambs and growth of dairy calves. Livestock Production Sci., 87, 207 - 214.

Van Soest, P.J., Robertson J.B. and Lewis, B.A. 1991. Methods for dietary fiber, neutral detergent fiber, and non-starch polysaccharides in relation to animal nutrition. J. Dairy Sci., 74, 3583-3597.

Warner, A.C.J. 1964. Production of volatile fatty acids in the rumen. Methods of Measurements. Nutr. Abst. \& Rev., 34, 339.-345.

Yang, W.Z., Beauchemin, K.A. and Rode, L.M. 1999. Effects of an enzyme feed additive on extent of digestion and milk production of lactating dairy cows. J. Dairy Sci., 82, 391-403.

Yang, W.Z., Beauchemin, K.A. and Vedres, D.D. 2002. Effects of $\mathrm{pH}$ and fibrolytic enzymes on digestibility, bacterial protein synthesis, and fermentation in continuous culture. Animal Feed Science and Technology, 102, 137-150

Yang, X., Zeng, Y., Ma, F., Zhang, X. and Yu, H. 2010. Effect of biopre treatment on thermo gravimetric and chemical characteristics of corn Stover by different white-rot fungi. Bioresources Technology,101, 5475-5483. 